\title{
Nutritional, Functional and Sensory Properties of Gari Enhanced with Fermented Maize Residues Flour
}

\section{Owuno Friday, Kiin-Kabari David Barine, Akusu Monday, Achinewhu Simeon Chituru}

Department of Food Science and Technology, Rivers State University, Port Harcourt, Nigeria

Email address:

kabaridavid@yahoo.com (Kiin-Kabari D. B.)

\section{To cite this article:}

Owuno Friday, Kiin-Kabari David Barine, Akusu Monday, Achinewhu Simeon Chituru. Nutritional, Functional and Sensory Properties of Gari Enhanced with Fermented Maize Residues Flour. International Journal of Food Science and Biotechnology.

Vol. 6, No. 2, 2021, pp. 59-65. doi: 10.11648/j.ijfsb.20210602.16

Received: May 25, 2021; Accepted: June 7, 2021; Published: June 21, 2021

\begin{abstract}
The by-product (residue) from fermented yellow maize starch production was dried and milled into flour and designated as fermented yellow maize residues, the residue was added to Gari at $0-30 \%$ levels of substitution to produce Gariresidue blends. The blends and control were evaluated for its functional and pasting properties, proximate composition, mineral content and starch digestibility. The Gari-residue blends were reconstituted with hot water into a stiff dough ("Eba") and its sensory and proximate composition analyzed. Results showed water and oil absorption capacities decreased, and an increase in Bulk density, swelling power and solubility index. Pasting property showed a decrease in peak, breakdown and setback viscosities, a decrease in pasting time while the pasting temperature increased. Proximate composition of stiff dough showed an increase in fat, crude protein and crude fibre with a decrease in carbohydrate content, mineral content determination showed the contents of $\mathrm{Ca}, \mathrm{Zn}, \mathrm{Fe}$ and $\mathrm{P}$ increased. Sensory evaluation results showed Gari stiff dough at 5-25\% levels of substitution had equal preference with the control for overall acceptability. Values for starch digestibility showed a reduction in glycemic indices with the presence of residue flours. This study has thus shown that fermented maize starch residue enhanced the sensory and nutritional properties of "Eba".
\end{abstract}

Keywords: Gari, "Eba”, Fermented Maize Residue, Pasting Properties, Sensory Properties, Nutritional Properties

\section{Introduction}

Gari is a fermented, gritty, starchy food or a free flowing granular product produced from cassava. Its use as a food source is limited by its perishability, low protein content and potential toxicity [1]. It is the most commonly consumed cassava product across most geopolitical zones in Nigeria and can be reconstituted with hot water to form a stiff paste or gel ('Eba') eaten usually with various vegetable soups or taken as a snack when soaked in cold water, sweetened with sugar and consumed with roasted groundnut, coconut or dry fish [2, 3].

Several attempts have been made by researchers to enhance the nutritional properties of Gari; through supplementation or fortification with food sources rich in protein and minerals and vitamins all of which are deficient in Gari and makes it a poor source of other nutrients apart from carbohydrate. Oluwamukomi enriched Gari with sesame seed flour and posited an increase in protein and fat content with a decrease in its content of carbohydrate [4].
Alozie and Ekerette fortified Gari with soybean, melon seed and Moringa seed flours and reported significant improvements in nutritive values of the gari products as well as enhanced sensory properties [3]. Onasoga et al. fortified gari with African breadfruit residue and they also reported an increase in nutritive value, sensory appeal and a decrease in a cyanide content [1].

Fermented maize residue is a by-product of "Ogi" production (fermented starch). It is the residue generated or left behind after the sieving process. The traditional preparation of Ogi involves soaking of maize kernels in water for 1-3 days and followed by wet milling and sieving to remove bran, hulls and germ [5]. The pomace (residue) which is retained on the sieve is later discarded or air dried as an ingredient for animal feed. Fermented maize residue apart from its substantial use as a feed stuff ingredient has also been found useful by households in Nigeria to increase the bulk of Gari stiff dough (Eba) with a more loosened texture.

Many food processing by-products are useful sources of 
nutrients and potential functional ingredients. Fermented maize residue which is now bereft of its starch content, with enhanced protein, fat, mineral and fibre content may contribute to increasing the nutritive value and sensory attributes of Gari and its stiff dough preparation (Eba).

This study was therefore aimed at investigating the nutrient composition, physicochemical properties as well as acceptability of Gari stiff dough enriched with fermented maize residue flour.

\section{Materials and Method}

\subsection{Production of Fermented Maize Residue}

The procedure for "Ogi" production was employed. One $\mathrm{kg}$ of maize was cleaned to remove dirts and soaked in $4000 \mathrm{ml}$ of water for 2 days. The soaked seeds were milled using a grinding mill, sieved and the filtrate allowed to stand for 2 hours. The top water was decanted and the sediment (slurry) bagged to allow more water to drain out. The resultant wet cake was Ogi.

The residue after sieving as earlier mentioned were dried at $50^{\circ} \mathrm{C}$ for 12 hour, milled using the dry mill component of a blender and packed in container until ready for use.

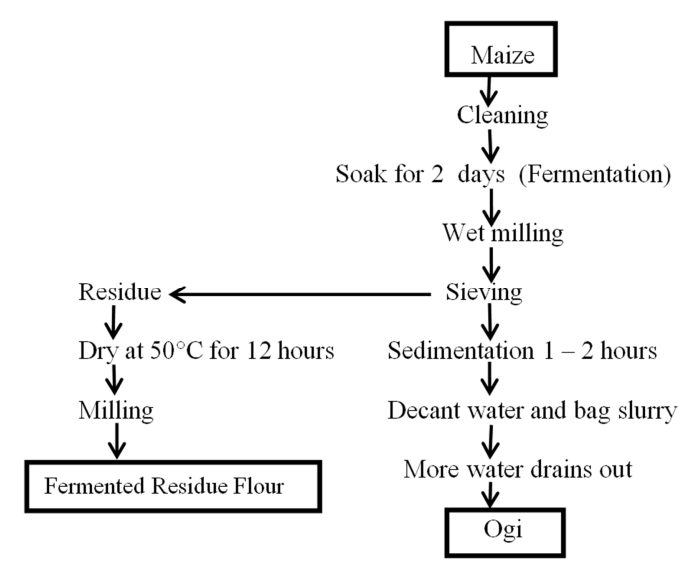

Figure 1. Flow diagram for fermented maize residue.

The composite flour blends for stiff dough preparations using Gari were formulated as shown in the table below:

Table 1. Gari-Maize Residue Composite Flour Blend.

\begin{tabular}{lll}
\hline Sample Code & Component A (Gari) & Component B (Residue) \\
\hline G0b & 100 & - \\
G1b & 95 & 5 \\
G2b & 90 & 10 \\
G3b & 85 & 15 \\
G4b & 80 & 20 \\
G5b & 75 & 25 \\
G6b & 70 & 30 \\
\hline
\end{tabular}

G0b:=Gari $100 \%$

$\mathrm{G} 1 \mathrm{~b}=\mathrm{Gari}+$ Residue at $5 \%$ substitution

$\mathrm{G} 2 \mathrm{~b}=\mathrm{Gari}+$ Residue at $10 \%$ substitution

$\mathrm{G} 3 \mathrm{~b}=\mathrm{Gari}+$ Residue at $15 \%$ substitution

$\mathrm{G} 4 \mathrm{~b}=\mathrm{Gari}+$ Residue at $20 \%$ substitution

$\mathrm{G} 5 \mathrm{~b}=\mathrm{Gari}+$ Residue at $25 \%$ substitution

$\mathrm{G} 6 \mathrm{~b}=\mathrm{Gari}+$ Residue at $30 \%$ substitution

\subsection{Functional Properties}

Water and Oil Absorption Capacities were determined using the method of Beuchat [6], bulk density by the method described by Wang and Kinsella [7], swelling volume, swelling power and solubility were carried out using the method of Takashi and Sieb [8].

\subsection{Pasting Properties}

The pasting properties of the gari and its blends were carried out using a Rapid Visco-Analyser (RVA model 3C, new port scientific Sydney) as described by Sanni et al., [9].

\subsection{Preparation of Gari-Residue Stiff Dough}

One hundred gram (100g) of Gari-composite flour blends as presented in Table 1 was weighed. $400 \mathrm{ml}$ of boiled water was added to the flour in a bowl and stirred with a wooden Gari turner until a well-mixed stiff dough was formed.

\subsection{Sensory Evaluation}

The Gari stiff dough (Eba) was evaluated for the following attributes of texture, colour, aroma and mouldability (Ease of rolling into balls on the palm of the hand), using a five-point hedonic scale by a twenty-member panelist consisting of women in the neighbourhood of Rivers State University staff quarters. The overall acceptability was calculated using the average score of all the attributes.

\subsection{Proximate Composition}

Proximate compositions were determined according to the methods of the Association of Official Analytical Chemist [10].

\subsection{Mineral Content}

The following minerals: $\mathrm{Ca}, \mathrm{Mg}, \mathrm{Zn}, \mathrm{Fe}$ and $\mathrm{P}$ were determined using the Atomic Absorption spectro photometer (Bulk Scientific-210V6P, USA) after preparation of their Ash solutions using the method of AOAC, [10].

\subsection{Glycemic Index Prediction}

The glycemic index prediction was carried out by the method of Goni et al., [11] as described by Kiin-Kabari and Giami [12].

\section{Results}

\subsection{Functional Properties}

Table 2 show result of functional properties of Garifermented yellow maize residue blend.

Water absorption capacity ranged from $3.47 \mathrm{~g} / \mathrm{g}$ in sample G6b to $4.38 \mathrm{~g} / \mathrm{g}$ in sample G0b, Oil Absorption Capacity $(\mathrm{g} / \mathrm{g})$ ranged from 1.62 in G5b to 1.84 in G0b, bulk density $(\mathrm{g} / \mathrm{ml})$ ranged from 0.59 in sample G0b and G1b to 0.72 in sample G6b, swelling power $(\mathrm{g} / \mathrm{g})$ ranged from 5.78 in $\mathrm{G} 0 \mathrm{~b}$ to 8.06 in G4b, swelling index (\%) ranged from 27.74 in G6b to 50.44 in G0b. 
Table 2. Functional Properties of Gari and Fermented Yellow Maize Residue Blends.

\begin{tabular}{|c|c|c|c|c|c|}
\hline Sample** & Water Absorption (g/g) & Oil Absorption (g/g) & Bulk Density (g/ml) & Swelling Power (glg) & Solubility Index (\%) \\
\hline G0b & $4.38^{\mathrm{a}} \pm 0.14$ & $1.84^{\mathrm{a}} \pm 0.01$ & $0.59^{\mathrm{d}} \pm 0.01$ & $5.78^{\mathrm{b}} \pm 0.50$ & $50.44^{\mathrm{a}} \pm 1.88$ \\
\hline G1b & $3.92^{\mathrm{a}} \pm 0.33$ & $1.71^{\mathrm{a}} \pm 0.12$ & $0.59^{\mathrm{d}} \pm 0.00$ & $5.86^{\mathrm{b}} \pm 0.43$ & $47.81^{\mathrm{ab}} \pm 0.99$ \\
\hline $\mathrm{G} 2 \mathrm{~b}$ & $3.89^{\mathrm{a}} \pm 0.42$ & $1.73^{\mathrm{a}} \pm 0.19$ & $0.62^{\mathrm{d}} \pm 0.01$ & $7.29^{\mathrm{ab}} \pm 0.36$ & $44.33^{\mathrm{b}} \pm 0.00$ \\
\hline $\mathrm{G} 3 \mathrm{~b}$ & $3.74^{\mathrm{a}} \pm 0.15$ & $1.70^{\mathrm{a}} \pm 0.02$ & $0.66^{\mathrm{c}} \pm 0.01$ & $6.76^{\mathrm{ab}} \pm 0.09$ & $37.04^{\mathrm{c}} \pm 0.06$ \\
\hline $\mathrm{G} 4 \mathrm{~b}$ & $3.81^{\mathrm{a}} \pm 0.22$ & $1.76^{\mathrm{a}} \pm 0.02$ & $0.69^{b} \pm 0.60$ & $8.06^{\mathrm{a}} \pm 0.42$ & $32.50^{\mathrm{cd}} \pm 1.64$ \\
\hline $\mathrm{G} 5 \mathrm{~b}$ & $3.76^{\mathrm{a}} \pm 0.02$ & $1.62^{\mathrm{a}} \pm 0.24$ & $0.70^{\mathrm{ab}} \pm 0.01$ & $7.87^{\mathrm{a}} \pm 0.70$ & $32.34^{\mathrm{d}} \pm 0.18$ \\
\hline G6b & $3.47^{\mathrm{a}} \pm 0.19$ & $1.70^{\mathrm{a}} \pm 0.05$ & $0.72^{\mathrm{a}} \pm 0.00$ & $7.48^{\mathrm{ab}} \pm 0.24$ & $27.74^{\mathrm{d}} \pm 1.56$ \\
\hline
\end{tabular}

* Values are Means of Duplicate Determinations \pm Standard Deviation.

Means with different superscript within a column are significantly different $(\mathrm{P}>0.05)$.

** Sample

$\mathrm{G} 0 \mathrm{~b}=100 \%$ Gari

$\mathrm{G}_{1} \mathrm{~b}=95 \%$ Gari: 5\% Residue Flour

$\mathrm{G}_{2} \mathrm{~b}=90 \%$ Gari: $10 \%$ Residue Flour

$\mathrm{G}_{3} \mathrm{~b}=85 \%$ Gari: $15 \%$ Residue Flour

$\mathrm{G}_{4} \mathrm{~b}=80 \%$ Gari: $20 \%$ Residue Flour

$\mathrm{G}_{5} \mathrm{~b}=75 \%$ Gari: $25 \%$ Residue Flour

$\mathrm{G}_{6} \mathrm{~b}=70 \%$ Gari: $30 \%$ Residue Flour

Table 3. *Pasting Properties of Gari and Fermented Yellow Maize Residue Blends.

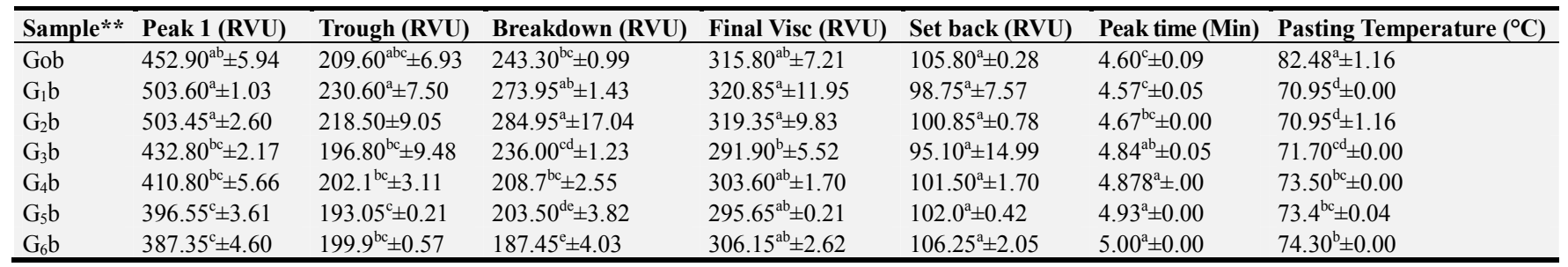

* Values are Means of Duplicate Determinations \pm Standard Deviation

Means with different superscript within a column are significantly different $(\mathrm{P}>0.05)$

** Sample

$\mathrm{G} 0 \mathrm{~b}=100 \%$ Gari

$\mathrm{G}_{1} \mathrm{~b}=95 \%$ Gari: 5\% Residue Flour

$\mathrm{G}_{2} \mathrm{~b}=90 \%$ Gari: 10\% Residue Flour

$\mathrm{G}_{3} \mathrm{~b}=85 \%$ Gari: $15 \%$ Residue Flour

$\mathrm{G}_{4} \mathrm{~b}=80 \%$ Gari: $20 \%$ Residue Flour

$\mathrm{G}_{5} \mathrm{~b}=75 \%$ Gari: $25 \%$ Residue Flour

$\mathrm{G}_{6} \mathrm{~b}=70 \%$ Gari: $30 \%$ Residue Flour

Table 4. Mean Sensory Scores of "Eba" from Yellow Gari-Fermented Yellow Maize Residue Blends.

\begin{tabular}{lllll}
\hline Sample & Colour & Texture & Aroma & Mouldability \\
\hline G0Y & $5.00^{\mathrm{a}} \pm 0.00$ & $4.84^{\mathrm{a}} \pm 0.37$ & $4.84^{\mathrm{a}} \pm 0.37$ & $4.84^{\mathrm{a}} \pm 0.37$ \\
G1Y & $4.62^{\mathrm{ab}} \pm 0.50$ & $4.61^{\mathrm{a}} \pm 0.76$ & $4.69^{\mathrm{ab}} \pm 0.63$ & $4.84^{\mathrm{a}} \pm 0.37$ \\
G2Y & $4.00^{\mathrm{abc}} \pm 1.00$ & $4.07^{\mathrm{ab}} \pm 0.86$ & $4.07^{\mathrm{ab}} \pm 1.11$ & $4.31^{\mathrm{a}} \pm 0.75$ \\
G3Y & $4.07^{\mathrm{abc}} \pm 0.86$ & $4.07^{\mathrm{a}} \pm 0.86$ & $4.00^{\mathrm{ab}} \pm 1.08$ & $4.68^{\mathrm{a}} \pm 0.41$ \\
G4Y & $3.92^{\mathrm{abc}} \pm 0.95$ & $4.23^{\mathrm{ab}} \pm 0.72$ & $4.07^{\mathrm{ab}} \pm 1.11$ & $4.11^{\mathrm{a}} \pm 0.80$ \\
G5Y & $3.15^{\mathrm{cd}} \pm 0.98$ & $3.53^{\mathrm{bc}} \pm 0.87$ & $3.62^{\mathrm{b}} \pm 1.04$ & $4.05^{\mathrm{ab}} \pm 0.72$ \\
G6Y & $3.00^{\mathrm{d}} \pm 1.08$ & $3.07^{\mathrm{c}} \pm 1.11$ & $3.61^{\mathrm{b}} \pm 1.26$ & $3.38^{\mathrm{b}} \pm 1.19$ \\
\hline
\end{tabular}

* Values are Means of Duplicate Determinations \pm Standard Deviation

Means with different superscript within a column are significantly different $(\mathrm{P}>0.05)$

** Sample

G0Y $=100 \%$ Gari

G1Y $=95 \%$ Gari: $5 \%$ Residue

G2Y $=90 \%$ Gari: $10 \%$ Residue

G3Y $=85 \%$ Gari: $15 \%$ Residue

G4Y $=80 \%$ Gari: $20 \%$ Residue

G5Y $=75 \%$ Gari: $25 \%$ Residue

G6Y $=70 \%$ Gari: $30 \%$ Residue

\subsection{Pasting Properties}

Table 3 showed results of pasting properties of Gari and fermented yellow maize residue blends. The Peak Viscosity ranged from 387.35 in G6b to 503.60 RVU in G1b, Trough Viscosity ranged from 193.05 in G5b to 230.60 RVU in G1b, 
Breakdown Viscosity ranged from 187.45 in G6b to 284.95 RVU in G2b, Final Viscosity ranged from 291.90 in G3b to 320.85 RVU in G1b, Setback Viscosity ranged from 95.10 in G3b to 106.25 RVU in G6b, Peak Time ranged from 4.57 in G1b to 5.00 mins in G6b while Pasting temperature ranged from 70.95 in $\mathrm{G} 1 \mathrm{~b}$ and $\mathrm{G} 2 \mathrm{~b}$ to $82.48^{\circ} \mathrm{C}$ in $\mathrm{G} 0 \mathrm{~b}$.

\subsection{Sensory Evaluation}

Table 4 showed the result of the mean sensory scores of "Eba" (Gari stiff dough) from yellow Gari-fermented yellow maize residue blend. The colour attribute ranged from 3.00 in G6Y to 5.00 in G0Y, texture ranged from 3.07 in G6Y to 4.84 in G0Y, Aroma ranged from 3.61 in G6Y to 4.84 in G0Y mouldability ranged from 3.31 in G6Y to 4.84 in G0Y and $\mathrm{G} 1 \mathrm{Y}$ with overall acceptability ranging from 3.25 in $\mathrm{G}_{6} \mathrm{Y}$ to 4.88 in G0Y.

\subsection{Proximate Composition}

Table 5 showed results of proximate composition of Yellow Gari-fermented yellow maize residue blends. Moisture content (\%) ranged from 9.98 in G5Y to 11.35 in G0Y, Ash (\%) ranged from 0.84 in G3Y to 1.24 in G0Y, Fat (\%) ranged from 1.00 in G0Y to 2.20 in G5Y, Crude protein (\%) ranged from 0.61 in G0Y to 4.11 in G6Y, Crude fibre (\%) ranged from 2.00 in G0Y to 9.18 while carbohydrate $(\%)$ ranged from 73.06 in G6Y to 83.81 in G0Y.

Table 5. Proximate Composition of Yellow Gari-Fermented Yellow Maize Residue Blends.

\begin{tabular}{|c|c|c|c|c|c|c|}
\hline Sample** & Moisture Content (\%) & $\operatorname{Ash}(\%)$ & Fat $(\%)$ & Crude Protein (\%) & Crude Fibre (\%) & Carbohydrate (\%) \\
\hline G0Y & $11.35^{\mathrm{a}} \pm 0.36$ & $1.24^{\mathrm{a}} \pm 0.05$ & $1.00^{\mathrm{d}} \pm 0.00$ & $0.61^{\mathrm{f}} \pm 0.00$ & $2.00^{\mathrm{d}} \pm 0.56$ & $83.81^{\mathrm{a}} \pm 0.98$ \\
\hline G1Y & $1.88^{\mathrm{a}} \pm 0.70$ & $1.23^{\mathrm{a}} \pm 0.19$ & $1.19^{\mathrm{cd}} \pm 0.01$ & $1.04^{\mathrm{ef}} \pm 0.01$ & $3.08^{\text {cd }} \pm 1.28$ & $82.08^{\mathrm{a}} \pm 0.09$ \\
\hline G2Y & $12.78^{\mathrm{a}} \pm 0.13$ & $1.19^{\mathrm{a}} \pm 0.13$ & $1.20^{\mathrm{cd}} \pm 0.28$ & $1.20^{\mathrm{de}} \pm 0.30$ & $4.88^{\mathrm{bcd}} \pm 0.12$ & $78.69^{\mathrm{a}} \pm 0.21$ \\
\hline G3Y & $12.19^{\mathrm{a}} \pm 0.72$ & $0.84^{\mathrm{a}} \pm 0.07$ & $1.48^{\mathrm{bcd}} \pm 0.12$ & $1.70^{\mathrm{d}} \pm 0.31$ & $5.11^{\mathrm{ab}} \pm 0.31$ & $78.68^{\mathrm{ab}} \pm 1.29$ \\
\hline G4Y & $12.66^{\mathrm{a}} \pm 2.36$ & $1.04^{\mathrm{a}} \pm 0.07$ & $1.80^{\mathrm{abc}} \pm 0.01$ & $2.36^{\mathrm{c}} \pm 0.00$ & $5.27^{\mathrm{bc}} \pm 0.66$ & $76.89^{\mathrm{ab}} \pm 2.93$ \\
\hline G5Y & $9.98^{\mathrm{a}} \pm 2.12$ & $1.04^{\mathrm{a}} \pm 0.07$ & $2.20^{\mathrm{a}} \pm 0.00$ & $3.2^{\mathrm{b}} \pm 0.02$ & $6.79^{\mathrm{ab}} \pm 1.40$ & $76.75^{\mathrm{ab}} \pm 3.59$ \\
\hline G6Y & $10.56^{\mathrm{a}} \pm 0.03$ & $1.10^{\mathrm{a}} \pm 0.01$ & $1.99^{\mathrm{ab}} \pm 0.26$ & $4.11^{\mathrm{a}} \pm 0.01$ & $9.18^{\mathrm{a}} \pm 0.41$ & $73.06^{\mathrm{b}} \pm 0.20$ \\
\hline
\end{tabular}

* Values are Means of Duplicate Determinations \pm Standard Deviation

Means with different superscript within a column are significantly different $(\mathrm{P}>0.05)$

** Sample

G0Y $=100 \%$ Gari

G1Y $=95 \%$ Gari: 5\% Residue Flour

G2Y $=90 \%$ Gari: $10 \%$ Residue Flour

G3Y $=85 \%$ Gari: $15 \%$ Residue Flour

G4Y $=80 \%$ Gari: $20 \%$ Residue Flour

G5Y $=75 \%$ Gari: $25 \%$ Residue Flour

G6Y $=70 \%$ Gari: 30\% Residue Flour

Table 6 showed results of proximate composition of 'Eba' (Gari-stiff dough) produced from Gari-fermented yellow maize residue blends. Moisture content (\%) ranged from 65.96 in G4Y to 70.32 in G2Y, Ash (\%) ranged from 0.36 in G5Y to 0.44 in G0Y, Fat (\%) ranged from 0.37 in G0Y to 0.77 in G5Y, Crude protein (\%) ranged from 0.22 in G0Y to 1.47 G6Y, Crude fibre (\%) ranged from 0.75 in G0Y to 3.29 in G6Y with carbohydrate (\%) ranging from 26.23 in G6Y to 30.25 in G0Y.

Table 6. *Proximate Composition of "Eba” Prepared from Yellow Gari-Fermented Yellow Maize Residue Blends.

\begin{tabular}{|c|c|c|c|c|c|c|}
\hline Sample** & Moisture Content (\%) & $\operatorname{Ash}(\%)$ & Fat $(\%)$ & Crude Protein (\%) & Crude Fibre (\%) & Carbohydrate (\%) \\
\hline G0Y & $67^{\mathrm{a}} \pm 0.40$ & $0.44^{\mathrm{a}} \pm 0.00$ & $0.37^{\mathrm{c}} \pm 0.00$ & $0.22^{\mathrm{d}} \pm 0.00$ & $0.75^{\mathrm{d}} \pm 0.20$ & $30.25^{\mathrm{a}} \pm 0.17$ \\
\hline G1Y & $69.67^{\mathrm{a}} \pm 2.28$ & $0.43^{\mathrm{a}} \pm 0.02$ & $0.41^{\mathrm{c}} \pm 0.02$ & $0.36^{\mathrm{cd}} \pm 0.03$ & $1.05^{\mathrm{cd}} \pm 0.36$ & $28.09^{a} \pm 2.60$ \\
\hline G2Y & $70.32^{\mathrm{a}} \pm 2.10$ & $0.41^{\mathrm{a}} \pm 0.07$ & $0.40^{c} \pm 0.07$ & $0.44^{\mathrm{cd}} \pm 0.13$ & $1.66^{\mathrm{bcd}} \pm 0.15$ & $26.78^{\mathrm{a}} \pm 1.81$ \\
\hline G4Y & $65.96^{\mathrm{a}} \pm 2.59$ & $0.41^{\mathrm{a}} \pm 0.07$ & $0.69^{\mathrm{ab}} \pm 0.03$ & $0.92^{\mathrm{b}} \pm 0.04$ & $2.04^{\mathrm{bc}} \pm 0.15$ & $29.98^{\mathrm{a}} \pm 2.62$ \\
\hline G5Y & $68.54^{\mathrm{a}} \pm 0.01$ & $0.36^{\mathrm{a}} \pm 0.03$ & $0.77^{\mathrm{a}} \pm 0.02$ & $1.13^{\mathrm{b}} \pm 0.02$ & $2.37^{\mathrm{ab}} \pm 0.54$ & $26.83^{\mathrm{a}} \pm 0.64$ \\
\hline G6Y & $67.91^{\mathrm{a}} \pm 0.09$ & $0.40^{\mathrm{a}} \pm 0.01$ & $0.71^{\mathrm{ab}} \pm 0.09$ & $1.47^{\mathrm{a}} \pm 0.01$ & $3.29^{\mathrm{a}} \pm 0.14$ & $26.23^{\mathrm{a}} \pm 0.13$ \\
\hline
\end{tabular}

* Values are Means of Duplicate Determinations \pm Standard Deviation

Means with different superscript within a column are significantly different $(\mathrm{P}>0.05)$

** Sample

$\mathrm{G} 0 \mathrm{Y}=100 \%$ Gari

G1Y $=95 \%$ Gari: 5\% Residue Flour

G2Y $=90 \%$ Gari: $10 \%$ Residue Flour

G3Y $=85 \%$ Gari: $15 \%$ Residue Flour

G4Y $=80 \%$ Gari: $20 \%$ Residue Flour

G5Y $=75 \%$ Gari: $25 \%$ Residue Flour

G6Y $=70 \%$ Gari: $30 \%$ Residue Flour

\subsection{Mineral Content}

Table 7 showed result of the mineral content of yellow Gari-fermented yellow maize residue. Value for calcium ranged from 
4.75 in sample G0Y to $9.42 \mathrm{mg} / 100 \mathrm{~g}$ in sample G3Y, Magnesium ranged from 2.50 in sample G6Y to $3.20 \mathrm{mg} / 100 \mathrm{~g}$ in sample G2Y, Zinc ranged from 0.05 in G0Y to $1.24 \mathrm{mg} / 100 \mathrm{~g}$ in sample G6Y, Iron ranged from 5.70 in G0Y to $8.88 \mathrm{mg} / 100 \mathrm{~g}$ in sample G6Y with Phosphorus ranging from 4.02 in sample G4Y to $4.67 \mathrm{mg} / 100 \mathrm{~g}$ in sample G6Y.

Table 7. Mineral Content (mg/100g) of Yellow Gari-Fermented Yellow Maize Residue.

\begin{tabular}{|c|c|c|c|c|c|}
\hline Sample & $\mathrm{Ca}$ & Mg & $\mathbf{Z n}$ & $\mathbf{F e}$ & $\mathbf{P}$ \\
\hline G0Y & $4.75^{\mathrm{e}} \pm 0.07$ & $3.07^{\mathrm{a}} \pm 0.00$ & $0.05^{\mathrm{d}} \pm 0.00$ & $5.70^{\mathrm{e}} \pm 0.00$ & $4.04^{\mathrm{de}} \pm 0.01$ \\
\hline G1Y & $5.97^{\mathrm{d}} \pm 0.04$ & $2.97^{\mathrm{ab}} \pm 0.01$ & $0.06^{\mathrm{d}} \pm 0.00$ & $5.91^{\mathrm{f}} \pm 0.01$ & $4.43^{\mathrm{b}} \pm 0.02$ \\
\hline G2Y & $8.05^{\mathrm{c}} \pm 0.00$ & $3.20^{\mathrm{a}} \pm 0.28$ & $0.23^{\mathrm{c}} \pm 0.04$ & $6.50^{\mathrm{d}} \pm 0.07$ & $4.13^{\mathrm{cd}} \pm 0.04$ \\
\hline G3Y & $9.42^{\mathrm{a}} \pm 0.02$ & $2.59^{\mathrm{b}} \pm 0.02$ & $0.14^{\mathrm{cd}} \pm 0.14$ & $7.12^{c} \pm 0.02$ & $4.49^{\mathrm{b}} \pm 0.00$ \\
\hline G4Y & $9.13^{\mathrm{b}} \pm 0.04$ & $3.08^{\mathrm{a}} \pm 0.05$ & $0.24^{\mathrm{c}} \pm 0.05$ & $8.86^{\mathrm{a}} \pm 0.00$ & $4.02^{\mathrm{e}} \pm 0.02$ \\
\hline G5Y & $9.07^{\mathrm{b}} \pm 0.02$ & $2.94^{\mathrm{ab}} \pm 0.02$ & $0.68^{\mathrm{b}} \pm 0.00$ & $8.42^{\mathrm{b}} \pm 0.02$ & $4.19^{c} \pm 0.00$ \\
\hline G6Y & $9.12^{\mathrm{b}} \pm 0.00$ & $2.50^{\mathrm{b}} \pm 0.09$ & $1.24^{\mathrm{a}} \pm 0.01$ & $8.88^{\mathrm{a}} \pm 0.02$ & $4.67^{\mathrm{a}} \pm 0.02$ \\
\hline
\end{tabular}

* Values are Means of Duplicate Determinations \pm Standard Deviation

Means with different superscript within a column are significantly different $(\mathrm{P}>0.05)$

** Sample

G0Y $=100 \%$ Gari

G1Y $=95 \%$ Gari: 5\% Residue

G2Y $=90 \%$ Gari: $10 \%$ Residue

G3Y $=85 \%$ Gari: $15 \%$ Residue

G4Y $=80 \%$ Gari: $20 \%$ Residue

G5Y $=75 \%$ Gari: $25 \%$ Residue

G6Y $=70 \%$ Gari: $30 \%$ Residue

\subsection{Glycemix Index}

Table 8 showed result of Glycemic Index of Garifermented white maize residue. The Glycemic Index (GI) ranged from $52.54 \%$ in sample G5Y to $64.59 \%$ in sample GOY.

Table 8. Glycemic Index of Gari-fermented Yellow Maize Residue.

\begin{tabular}{ll}
\hline Samples & GI $(\mathbf{\%})$ \\
\hline GOY & $64.59^{\mathrm{a}} \pm 0.001$ \\
G1Y & $57.31^{\mathrm{b}} \pm 0.007$ \\
G2Y & $53.93^{\mathrm{c}} \pm 0.003$ \\
G3Y & $53.74^{\mathrm{d}} \pm 0.003$ \\
G4Y & $53.04^{\mathrm{e}} \pm 0.006$ \\
G5Y & $52.54^{\mathrm{f}} \pm 0.004$ \\
G6Y & $53.92^{\mathrm{c}} \pm 0.003$ \\
\hline
\end{tabular}

Means with the same superscript in the same column show that there is no significant difference $(\mathrm{P}>0.05)$.

$\mathrm{G} 0 \mathrm{Y}=100 \%$ Gari

G1Y $=95 \%$ Gari: 5\% Residue

G2Y $=90 \%$ Gari: $10 \%$ Residue

G3Y $=85 \%$ Gari: $15 \%$ Residue

G4Y $=80 \%$ Gari: $20 \%$ Residue

G5Y $=75 \%$ Gari: $25 \%$ Residue

G6Y $=70 \%$ Gari: $30 \%$ Residue

\section{Discussions}

\section{Result of Functional Properties}

Results of functional properties showed Water Absorption Capacity (WAC) decreased with increase in the amount of residue flour from $4.38 \mathrm{~g} / \mathrm{g}$ in the control to $3.47 \mathrm{~g} / \mathrm{g}$ in sample G6b (30\% residue addition). Gari has a high water absorption capacity and a dilution effect with a fibre residue will obviously lead to a decrease in it WAC. The Oil Absorption Capacity (OAC) also decreased but by way of comparison the WAC of the blends were higher than the OAC.

The bulk density increased with increase in the content of the residue flour, from $0.59 \mathrm{~g} / \mathrm{ml}$ in the control (G0b) and GI0 to $0.70 \mathrm{~g} / \mathrm{ml}$ in sample G5b. The increase could possibly be as a result of the fact that the Gari has a higher density when compared to the maize residue and being a gelatinized product is more compact in its structure and so the addition of the residue was not sufficient to decrease its overall density thereby making it to have more weight per volume. The values for swelling power increased with substitution and also could be a function of the WAC of the added fibre residue. Swelling power increased from $5.78 \mathrm{~g} / \mathrm{g}$ in the control to $8.36 \mathrm{~g} / \mathrm{g}$ in sample G46 (20\% level of substitution), though the results did not show a gradation with increase in substitution levels. The solubility index (\%) decreased from $50.44 \%$ in the control to $29.74 \%$ in sample G6b (30\% substitution). The decreased solubility could be as a result of the insoluble fibre content of the fermented maize residue. Insoluble fibre are major constituents of whole grains. Ozyurt and Otles [13] reported whole grain cereals contain greater quantities of insoluble fibre and that the type of dietary fibre either soluble or insoluble define their physical behavior in water.

The pasting characteristics of Gari-fermented yellow maize residue blends show the peak viscosity decreased with increase in residue flours. Trough also followed the same pattern as observed except at G1b (5\% residue) and G2b (10\% residue) but overall values for trough decreased. Breakdown viscosity also increased at G2b at 10\% levels of substitution before a decrease. The final viscosity also increased at 5 and $10 \%$ levels of substitution at sample G1b and G2b. Final viscosity increased at 5 and $10 \%$ levels of substitution, decreased at $15 \%$ (G3b), $20 \%$ (G4b), 25\% (G5b) and 30\% (G6b). Setback viscosity decreased upto G5b (25\% residue) before an increase at $30 \%$ level of substitution. Pasting temperature decreased from the control while the pasting time increased with residue content.

Mean sensory scores of "Eba" from yellow Gari-fermented yellow maize residue blend show the control sample (G0Y) 
was the most preferred for colour with a score of 5.0 and followed closely by G1Y with a score of 4.62, G3Y with a score of 4.07 and G2Y with a score of 4.00, sample G6Y with $30 \%$ level of substitution was the least preferred with a score of 3.00. For texture the control sample was still the most preferred with a score of 4.84 and followed closely by G1Y (4.61), G4Y (4.23) and G2Y and G3Y with a score of 4.07, the least preferred sample for texture is sample G6Y (3.07). Sample GOY was still the most preferred for Aroma (4.84) though value did not differ significantly from samples G1Y, G2Y and G3Y G3Y and G4Y. For mouldability (ease of moulding) sample GOY and G1Y were the most preferred with sensory scores of 4.84 , but value did not differ significantly from samples G2Y, samples G3Y, samples G5Y and G6Y were the least preferred but values did not differ significantly from G2Y, G3Y. For overall acceptability, samples GOY and G1Y were the most preferred with scores of 4.88 and 4.69 , but the values did not differ significantly from G2Y, G3Y and G4Y, sample G5Y and G6Y had equal preference and their means were not significantly different. The results thus show that for the sensory attributes of overall acceptability Eba at 5, 10, 15 and $20 \%$ levels of substitution with fermented yellow maize residue compared favourably with the control as the mean sensory scores did not differ significantly $(\mathrm{P}>0.05)$. Oluwamukomi [4] reported that addition of defatted sesame to Gari gave acceptable Eba at 10\% level of substitution.

The moisture content (\%) of Gari ranged from 9.98 in GOY to 12.78 in $\mathrm{G} 2 \mathrm{Y}$, values were not significantly different $(\mathrm{P}>$ 0.05) and are within ranges for Gari samples, Akume et al., [14] reported moisture contents of $8.55-12.60 \%$ in Gari fortified with mango fruit mesocarp. Awoyale et al., gave values of moisture content of Gari of between 3.53-7.25\% [15]. Values for ash dropped with increase in the presence of residue flour from 1.24 in the control to $0.84 \%$ in G3Y. Akume et al., also presented a decrease in ash content of Gari fortified with mango mesocarp, from 2.94 in the control to 2.30 at $30 \%$ level of substitution with mango fruit mesocarp flour [14]. The fat content also increased from the control (1.00) to $2.20 \%$ in G5Y. Alozie and Ekerette indicated an increase in fat content of Gari fortified with soybean, melon seed and moringa seed flour. The values for fat as reported increased from the control, $6.34 \%$ to $10.74 \%$ for melon seed Gari, $8.81 \%$ for soy Gari and $7.6 \%$ for moringa seed Gari [3]. Crude protein (\%) increased from 0.61 in the control to 4.11 in G6Y (30\% substitution level). Akume et al., also reported an increase in protein of Gari from 1.01 in the control to $1.42 \%$ at $30 \%$ substitution level with mango fruit mesocarp [14], Onasoga et al., also reported an increase in protein content of Gari composited with African bread fruit residue from 1.96 in the control to $9.62 \%$ at $30 \%$ level of substitution [1]. Crude fibre also increased with residue substitution while values of carbohydrate decreased with increase in substitution with residue flour. Proximate composition of "Eba" showed Moisture content ranged from $65.96-70.32 \%$ and did not show any significant difference among the means, values for ash was also not significantly different, result for fat showed an increase with substitution with residue flours with sample G5Y and G6Y (25\% and 30\% residue addition) being significantly different from all others. Results for crude protein and crude fibre also follow the observed trend as values increased with residue substitution with sample G6Y being significantly different from others while carbohydrate decreased with substitution and the values did not show any significant difference among the means.

The addition of maize residue increased the calcium content of the Gari from $4.75 \mathrm{mg} / 100 \mathrm{~g}$ in the control to $9.18 \mathrm{mg} / 100 \mathrm{~g}$. Akume et al., [14] also reported an increase in the calcium content of Gari supplemented with mango fruit mesocarp.

The values for the control $4.75 \mathrm{mg} / 100 \mathrm{~g}$ was higher than $1.02 \mathrm{mg} / 100 \mathrm{~g}$ reported by [16] and lesser than 16.20 $\mathrm{mg} / 100 \mathrm{~g}$ and $9.2 \mathrm{mg} / 100 \mathrm{~g}$ reported by $[17,18]$.

Result for magnesium showed no defined pattern as to the effect of residue addition on the magnesium content but values were least in sample G6Y with 30\% residue addition with samples G0Y, G2Y and G4Y being significantly different.

Results for Zinc showed the content of Zinc increased with residue addition from $0.05 \mathrm{mg} / 100 \mathrm{~g}$ in G0Y to $1.24 \mathrm{mg} / 100 \mathrm{~g}$ in G6Y. Values for Iron (Fe) increased from $5.70 \mathrm{mg} / 100 \mathrm{~g}$ in G0y to $8.88 \mathrm{mg} / 100 \mathrm{~g}$ in G6y, thus showing an increase in the Iron content of the Gari samples with maize residue addition with samples G4y and G6y being significantly different. Result for phosphorus showed an increase in phosphorus content with residue flour addition from $4.04 \mathrm{mg} / 100 \mathrm{~g}$ in the control to 4.67 $\mathrm{mg} / 100 \mathrm{~g}$ in the highest level of substitution G6Y.

The addition of residue also reduced the value of Glycemic Index (GI) from $64.59 \%$ in the control to $52.54 \%$ in sample G5Y with $25 \%$ level of substitution with residue flours.

The reduction in GI upon addition of residue flours can be attributed to the fact that the fibre flour increases the indigestible carbohydrate content of the gari samples.

In the classification of resistance starch into their further sub-class of type 1 , type 2 , type 3 and type 4 , partly milled grain and seeds were classified as resistant starch, so the reduction in the GI of the samples from the control can also be adduced to a likely increase in its content of resistant starch.

Scazzina et al., reported that high contents of indigestible carbohydrate in products such as bread has a beneficial effect on glyceamic response [19]. Glyceamic response refers to the effect of food on blood glucose after consumption. Krawecka et al., also reported that Dietary fibre as a group of compounds comprising plant polysaccharides, oligosaccharides, lignins, fructans and $\beta$-glucans does not increase the level of glycaemia and also reported that cereal grains are rich mainly in the insoluble fraction of dietary fibre, and the greatest amount of fibres are found in wholegrain milled products and that higher consumption of such products is associated with reduction of the type 2 diabetes risk in subjects with glucose intolerance. They also indicated that the glyceamic response of bread appears to be lower after the incorporation of whole or cracked rye or barley grains [20].

\section{Conclusions}

Addition of fermented maize residue led to a decrease in 
water absorption capacity a decrease in oil absorption capacities, increase bulk density and swelling power while solubility decreased. This study also shows that addition of the residue also affected pasting properties, increased the content of protein, crude fibre, fat with a decrease in carbohydrate content. Result of sensory evaluation of "Eba" showed that for overall acceptability levels of substitution upto $20 \%$ compared favourably with the control. The content of $\mathrm{Ca}, \mathrm{Zn}, \mathrm{P}$ and $\mathrm{Fe}$ content increased with addition of the fermented Maize residue. This study also shows a decrease in glycemic index of Gari upon the addition of residue flours. This study thus suggests that fermented maize residue can find utilization in human food formulations. Further studies to evaluate the prebiotic and probiotic potentials of food products with fermented maize residue addition is recommended.

\section{References}

[1] Onasoga, M. O., Ayodele, D. and Oyeyipo, O. O. (2014). Chemical changes during the fortification of cassava meal (Gari) with African breadfruit residue. Journal of Applied Science Environment and Management, 18 (3), 506-512.

[2] Sanni, M. O. and Sobamiwa, A. O. (1994). Processing and characteristics of soybean-fortified Gari. W. J. of Microbiol and Biotechnology, 18, 85-95.

[3] Alozie, Y. E. and Ekerette, N. N. (2017). Proximate compositions, Physicochemical and Sensory Properties of Gari Fortified with Soybean, Melon seed and Moringa Seed flours. International Journal of Nutritional and Food Science, $6(2), 105-110$.

[4] Oluwamukomi, M. O. (2015). Chemical and sensory properties of Gari enriched with sesame seed flour. Futa Journal of Research In Science, 1, 123-131.

[5] Odunfa, S. A. and Adeyele, S. (1985). Microbiological changes during the traditional production of "Ogi-baba"-A West African fermented sorghum gruel. Journal of Cereal Science, 12, 173-180.

[6] Beuchat, L. R. (1977). Functional and electrophoretic characteristics of succunylated peanut flour protein. $J$. of Agriculture and Food Chemistry, 25, 258-262.

[7] Wang, J. C. and Kinsella, J. E. (1976). Functional properties of novel proteins. Alfalfa leaf protein. Journal. of Food Science, 41, 286-289.

[8] Takashi, S. and Sieb, P. A. (1988). Paste and gel properties of prime corn and wheat starches with and without native lipids. Cereal Chemistry, 65, 474-483.
[9] Sanni, L., Maziya-Dixon, B., Onabolu, A. O., Arowosa-FP, B. E., Okechukwu, R. U., Aixon, A. G. O., Waziri, A. D. F., Ezedinma, C., Ssemakula, G., Lemchi, J. I. Akoroda, M., Ogbe, F., Farawal, G., Okoro, E. and Geteloma, C. (2006). Cassava Recipes for Household Food Security, International Institute of Tropical Agriculture, (IITA), Integrated cassava project, Ibadan, Nigeria.

[10] AOAC. (1990). Official method of analysis, Washington DC, USA, Association of Official Analytical Chemist.

[11] Goni, I., Garci-Alonso, A. and Surara-Calirto, B. (1997). Starch hydrolysis procedure to estimate glycemic. Nutrition Research, 17, 427-437.

[12] Kiin-Kabari, D. B. and Giami, S. Y. (2016). Invitro Starch Hydrolysis and Prediction of Glycemic Index (PCAI) in "Amala" and Plantain Based Baked Products. Journal of Food Research, 5 (2), 73-80.

[13] Ozyurt, V. H. and Otles, S. (2016). Effect of food processing on the physicochemical properties of dietary fibre. Acta Science Polish Technology Aliment., 15 (3), 233-245.

[14] Akume. N. J., Ariahu, C. Charles and Acham, O. I. (2019). Quality evaluation of ready to eat Garri made from cassava mash and mango fruit mesocarp blends. Asian food science Journal, 8 (3), 1-9.

[15] Awoyale, W., Kawalawu, W. k. S., Asiedu, R., Maziya-Dixon, B., Abass, A. \& Edeth, M. (2019). Evaluation of the chemical composition and functional properties of Gari from Liberia. Croatian Journal of Food Science and Technology, 11, 157167.

[16] Oluwaseun, P. B., Femi, G. O., Basirat, A. O., Mofoluwaso, B. F. and Olayide, W. B. (2014). Nutritional composition of gari analogue produced from cassava and cocoyam tuber. Food Science Nutritional, 2 (6), 706-711.

[17] Ajifoloku, O. M. and Adeniran, H. A. (2018). Proximate composition and mineral composition of co-fermented bread fruit and cassava into gari analogue, Journal of Nutrition Food Science, 8, 658 .

[18] Silifat, A. J., Clara, R. B. and Ogunto, B. M. (2010). Chemical composition, pasting and sensory properties of Iron-Fortified Cassava Gari. Food, 4, 55-60.

[19] Scazzina, F., Siebenhandl-Ehn, S. and Pellegrini, N. (2013). The effect of dietary fibre on reducing the glycaemic index of bread. British Journal of Nutrition; 109, 1163-1174.

[20] Krawecka, A., Sobota, A. and Sykut-Domanska, E. (2019). Functional cereal products in the Diet for Type 2 Diabetes patients. International Journal of Food Science, 412-418. 